\title{
Front Matter: Volume 9587
}

, "Front Matter: Volume 9587," Proc. SPIE 9587, Optical Data Storage 2015, 958701 (2 September 2015); doi: 10.1117/12.2217974

SPIE Event: SPIE Optical Engineering + Applications, 2015, San Diego, California, SPIE. United States 


\section{PROCEEDINGS OF SPIE}

\section{Optical Data Storage 2015}

Ryuichi Katayama

Thomas D. Milster

Editors

\section{August 2015}

San Diego, California, United States

Sponsored and Published by

SPIE 
The papers in this volume were part of the technical conference cited on the cover and title page. Papers were selected and subject to review by the editors and conference program committee. Some conference presentations may not be available for publication. Additional papers and presentation recordings may be available online in the SPIE Digital Library at SPIEDigitallibrary.org.

The papers published in these proceedings reflect the work and thoughts of the authors and are published herein as submitted. The publisher is not responsible for the validity of the information or for any outcomes resulting from reliance thereon.

Please use the following format to cite material from this proceedings:

Author(s), "Title of Paper," in Optical Data Storage 2015, edited by Ryuichi Katayama, Thomas D. Milster, Proceedings of SPIE Vol. 9587 (SPIE, Bellingham, WA, 2015) Six-digit Article CID Number.

ISSN: 0277-786X

ISSN: 1996-756X (electronic)

ISBN: 9781628417531

Published by

SPIE

P.O. Box 10, Bellingham, Washington 98227-0010 USA

Telephone +1 3606763290 (Pacific Time) · Fax +1 3606471445

SPIE.org

Copyright (C) 2015, Society of Photo-Optical Instrumentation Engineers.

Copying of material in this book for internal or personal use, or for the internal or personal use of specific clients, beyond the fair use provisions granted by the U.S. Copyright Law is authorized by SPIE subject to payment of copying fees. The Transactional Reporting Service base fee for this volume is $\$ 18.00$ per article (or portion thereof), which should be paid directly to the Copyright Clearance Center (CCC), 222 Rosewood Drive, Danvers, MA 01923. Payment may also be made electronically through CCC Online at copyright.com. Other copying for republication, resale, advertising or promotion, or any form of systematic or multiple reproduction of any material in this book is prohibited except with permission in writing from the publisher. The CCC fee code is 0277-786X/15/\$18.00.

Printed in the United States of America.

Publication of record for individual papers is online in the SPIE Digital Library.

\section{SPIE. DIGITAL}

Paper Numbering: Proceedings of SPIE follow an e-First publication model. A unique citation identifier (CID) number is assigned to each article at the time of publication. Utilization of CIDs allows articles to be fully citable as soon as they are published online, and connects the same identifier to all online and print versions of the publication. SPIE uses a six-digit CID article numbering system structured as follows:

- The first four digits correspond to the SPIE volume number.

- The last two digits indicate publication order within the volume using a Base 36 numbering system employing both numerals and letters. These two-number sets start with $00,01,02,03,04$, $05,06,07,08,09,0 A, 0 B \ldots$. OZ, followed by 10-1Z, 20-2Z, etc. The CID Number appears on each page of the manuscript. 


\title{
Contents
}

\author{
$\checkmark \quad$ Authors \\ vii Conference Committee \\ ix Introduction
}

\section{SESSION 1 HOLOGRAPHIC DATA STORAGE I}

958702 Multi-terabit/in ${ }^{2}$ holographic data storage demonstration (Invited Paper) [9587-1]

958703 Numerical evaluation of multilayer holographic data storage with a varifocal lens generated with a spatial light modulator [9587-2]

958704 Design of binary data page with a phase mask for high-density holographic recording [9587-3]

958705 Optimization of holographic data storage system based on Seidel aberrations reduction [9587-4]

\section{SESSION 2 HOLOGRAPHIC DATA STORAGE II}

958707 Quantitative roadmap of holographic media performance (Invited Paper) [9587-6]

958708 High dynamic range holographic data storage media [9587-7]

958709 Proposal for one-beam microholographic recording using radially polarized light beam [9587-8]

\section{SESSION 3 EMERGING AND ELEMENTAL TECHNOLOGIES}

9587 OC Multilayer optical data storage by fluorescence modulation using a CW laser (Invited Paper) [9587-11]

9587 OE Optimized six-dimensional optical storage: a practicable way to large capacity and fast throughputs [9587-13]

SESSION 4 HOLOGRAPHIC DATA STORAGE III

9587 OF Modeling and measures against the effect of mechanical instabilities on holographic data storage system (Invited Paper) [9587-14] 
9587 OG Enhancement of data rates by single and double cavity holographic recording [9587-15]

$9587 \mathrm{OH}$ Volume holography with Bessel-like reference beams [9587-17] 


\title{
Authors
}

Numbers in the index correspond to the last two digits of the six-digit citation identifier (CID) article numbering system used in Proceedings of SPIE. The first four digits reflect the volume number. Base 36 numbering is employed for the last two digits and indicates the order of articles within the volume. Numbers start with 00, 01, 02, 03, 04, 05, 06, 07, 08, 09, 0A, 0B...0Z, followed by 10-1Z, 20-2Z, etc.

\author{
Anderson, Ken, 02 \\ Askham, Fred, 02, 08 \\ Ayres, Mark R., 02, 08 \\ Baer, Eric, OC \\ Barada, Daisuke, 04 \\ Christenson, Cory W., OC \\ Guerrero, Raphael A., $\mathrm{OH}$ \\ Hoshizawa, Taku, OF \\ Hsu, Ken-Yuh, 05 \\ Ishii, Toshiki, OF \\ Katayama, Ryuichi, 09 \\ Kawata, Shigeo, 04 \\ Kowalski, Benjamin A., 07 \\ Lin, Shivan-Huei, 05 \\ Liu, Ren-Chung, 05 \\ Liu, Shangqing, $\mathrm{OE}$ \\ Manigo, Jonathan P., OH \\ McLeod, Robert R., 07 \\ Miller, Bo E., OG \\ Mirletz, Heather, OC \\ Nobukawa, Teruyoshi, 03 \\ Nomura, Takanori, 03 \\ Ryan, Christopher J., OC \\ Saini, Anuj, OC \\ Shimada, Ken-ichi, OF \\ Shiyanovskaya, Irina, OC \\ Singer, Kenneth D., OC \\ Sissom, Brad, 02 \\ Takashima, Yuzuru, OF, OG \\ Urness, Adam C., 02, 08 \\ Yatagai, Toyohiko, 04 \\ Yin, Kezhen, OC
}


Proc. of SPIE Vol. $9587958701-6$

Downloaded From: https://www.spiedigitallibrary.org/conference-proceedings-of-spie on 26 Apr 2023 Terms of Use: https://www.spiedigitallibrary.org/terms-of-use 


\section{Conference Committee}

Program Track Chairs

Shizhuo Yin, The Pennsylvania State University (United States)

Ruyan Guo, The University of Texas at San Antonio (United States)

Conference Chairs

Ryuichi Katayama, Fukuoka Institute of Technology (Japan)

Thomas D. Milster, College of Optical Sciences, The University of Arizona (United States)

Conference Program Committee

Mark R. Ayres, Akonia Holographics, LLC (United States)

Min Gu, Swinburne University of Technology (Australia)

Luping Shi, Tsinghua University (China)

Kenichi Shimada, Hitachi, Ltd. (Japan)

Yuzuru Takashima, College of Optical Sciences, The University of Arizona (United States)

Din Ping Tsai, National Taiwan University (Taiwan)

\section{Session Chairs}

1 Holographic Data Storage I

Kenichi Shimada, Hitachi, Ltd. (Japan)

2 Holographic Data Storage II

Mark R. Ayres, Akonia Holographics, LLC (United States)

3 Emerging and Elemental Technologies

Ryuichi Katayama, Fukuoka Institute of Technology (Japan)

4 Holographic Data Storage III

Yuzuru Takashima, College of Optical Sciences, The University of Arizona (United States) 
Proc. of SPIE Vol. $9587958701-8$

Downloaded From: https://www.spiedigitallibrary.org/conference-proceedings-of-spie on 26 Apr 2023 Terms of Use: https://www.spiedigitallibrary.org/terms-of-use 


\section{Introduction}

This proceedings volume is a collection of papers based on the invited and contributed presentations at the Optical Data Storage (ODS) 2015 conference, held on August 9th, 2015 at the San Diego Convention Center as part of SPIE Optics + Photonics 2015 .

ODS 2015 was the second ODS conference held as a part of SPIE Optics + Photonics, following ODS 2014. After ODS 2014, we conducted a brief survey on future ODS conferences for the attendees. The main results were as follows. Regarding the style, all attendees liked to continue to have the ODS conferences as part of larger conferences. Regarding the appropriate frequency, the majority opinion was that we should have the ODS conference every year rather than every two years to maintain our momentum even if there would be little material. Based on these results, we decided to hold the ODS 2015 in the same style as that of the ODS 2014.

The ODS 2015 was basically a good success. A total of 16 papers ( 7 invited papers and 9 contributed papers) were presented orally. One paper, 9587-4, cancelled because of a strong typhoon, but is included in this Proceedings volume. There were some high-quality presentations about holographic data storage as well as emerging and elemental technologies. One thing we have to regret is that we had no presentations about heat-assisted magnetic recording this year, we had a lot last year. Nevertheless, the average number of attendees for each session this year was almost the same as that last year.

We are very happy that a total of 12 papers are contained in this Proceedings volume. They represent important and interesting achievements in the current field of optical data storage. We hope that the readers find this Proceedings volume stimulating and exciting as well as helpful for their future research and development.

Finally, we would like to express our sincere gratitude to the committee members, session chairs, and all of the presenters and attendees of ODS 2015, as well as the SPIE staff for their great contribution. We are planning to have ODS 2016 as part of SPIE Optics + Photonics 2016, which will be officially announced later.

Ryuichi Katayama Thomas D. Milster 
Proc. of SPIE Vol. 9587 958701-10

Downloaded From: https://www.spiedigitallibrary.org/conference-proceedings-of-spie on 26 Apr 2023 Terms of Use: https://www.spiedigitallibrary.org/terms-of-use 